\title{
ITEM System Usage in the Ministry of Education in Botswana
}

\author{
Omponoye C. Kereteletse and Ian Selwood \\ Ministry of Education IT Unit, Gaborone, Botswana \\ The University of Birmingham, School of Education, Edgbaston, Birmingham, UK \\ I.D. Selwood@Bham.AC.UK
}

\begin{abstract}
In this paper some of the results of a study that evaluated system usage of the computerised information system implemented by the Ministry of Education (MoE) in Botswana are presented. The system was implemented to manage the teaching human resource. Evaluation of the use of this new system was based on the users' perception of their ability to use the ITEM system directly, or indirectly, and a detailed analysis of factors that influence system usage. The magnitude of external training, perceived quality of information provided, and computer experience of the MoE staff explained considerable amounts of variance in direct use of the system implemented by the MoE in Botswana. Whereas the amount of external training, and perceived quality of information provided and output options explained considerable amounts of variance in indirect use of the system implemented by the MoE in Botswana.
\end{abstract}

Key words: Educational management, system usage, system quality, implementation, organisation.

\section{BACKGROUND}

Botswana is a developing country with a highly centralised system for managing education. Due to the rapid expansion of the education system, the manual system of managing the teaching workforce was not working efficiently or effectively. In 1994, a new education policy had been adopted 'The Revised National Policy on Education' (RNPE) (MoE, 1994). The RNPE reported a massive expansion of pupils in schools, but that academic standards were declining. Furthermore, RNPE noted that the effective management of the teaching resource was seen as paramount to expanding 
education and maintaining quality. However, in spite of the reorganisation of the Department of Teaching Service Management, problems persisted with regard to the service delivery of the department. The Botswana Ministry of Education (MoE) decided to implement a computerised system for managing the teaching resource, based on Infinium Software and this went live on $3^{\text {rd }}$ May 1999, and the implementation process was analysed by Kereteletswe and Selwood (2003). This paper evaluates the system usage of the implemented computerised information system.

\section{RESEARCH FRAMEWORK}

According to Visscher, (1995) system use is related to system quality, implementation process features, and organisational process features. Hence, the impact of system quality, implementation process features, and organisational process features on direct and indirect usage of the implemented system were investigated. Three system quality characteristics: software quality, information quality, and quality of output options, were considered in the analysis. Five characteristics of the implementation process features were considered: external training, internal training, clarity of innovation goals, clarity of means, and technical team performance. Internal training and clarity of means were excluded from the analysis due to the incidence of numerous missing values. The variables that constituted the organisational features were the system (Infinium HR) goals, motivation before implementation, and computer experience.

\section{METHOD AND DATA ANALYSIS}

A total of 168 questionnaires were distributed to staff in the $\mathrm{MoE}$ Departments involved in the management of teachers. These were Teaching Service Management, Secondary Education, Primary Education, and Regional Education Offices. The questionnaire was completed by clerical staff, secretaries, personal assistants, middle managers, and top managers.

A response rate of $76 \%$ (127 out of 168) was achieved. Of the 127 questionnaires returned, eleven were excluded from the analysis as they had numerous blanks. Users rated their subjective state on various 6-point scales. The categorical data of the independent variables were coded and scores for the dependent variable 'direct and indirect use' on the interval scale ( 0 hours to greater than 6 hours per week) were converted to z-scores. This standardisation paved the way to the manipulation of the attitude levels across context, using each respondent's mean in the standard comparison. To 
little change in the sum of squares, and the df (degrees of freedom) was 3 in model 1, reduced to 2 in model 2 and then to 1 in model 3. However, Model 3 is adopted since the other two independent variables 'software quality' and 'output of data quality options' did not have any significant relationship with direct use of the Infinium HR system by MoE, as shown in Table 2.

Table 2. System quality features influence on direct use

\begin{tabular}{|c|c|c|c|c|c|c|}
\hline Model & Main effects & $\begin{array}{c}\text { Unstandardised } \\
\text { Coefficients Beta }\end{array}$ & $\begin{array}{l}\text { Std. } \\
\text { Error }\end{array}$ & $\begin{array}{c}\text { Standardised } \\
\text { Coefficients Beta }\end{array}$ & $\mathrm{t}$ & $\begin{array}{c}\text { Significance } \\
\text { of } F\end{array}$ \\
\hline \multirow[t]{4}{*}{1} & (Constant) & 3.792 & .679 & & 5.581 & .000 \\
\hline & $\begin{array}{l}\text { Information } \\
\text { quality }\end{array}$ & .628 & .251 & .238 & 2.499 & .014 \\
\hline & $\begin{array}{l}\text { Quality of output } \\
\text { options }\end{array}$ & .318 & .283 & .106 & 1.124 & .164 \\
\hline & Software quality & .462 & .456 & .092 & 1.014 & .313 \\
\hline \multirow[t]{3}{*}{2} & (Constant) & 3.358 & .528 & & 6.358 & .000 \\
\hline & $\begin{array}{l}\text { Information } \\
\text { quality }\end{array}$ & .662 & .249 & .250 & 2.657 & .019 \\
\hline & $\begin{array}{l}\text { Quality of data } \\
\text { output options }\end{array}$ & .326 & .283 & .109 & 1.154 & .052 \\
\hline \multirow[t]{2}{*}{3} & (Constant) & 2.897 & .345 & & 8.387 & .000 \\
\hline & $\begin{array}{l}\text { Information } \\
\text { quality }\end{array}$ & .746 & .239 & .282 & 3.127 & .000 \\
\hline
\end{tabular}

a. Dependent Variable: DIRECT

Table 2 shows the significance of $F$ for the remaining independent variable, information quality in model 3 at 0.000 which is less than $p=0.05$. Therefore, there is a significant relationship between information quality and the direct use of the Infinium HR system in the MoE in Botswana.

More importantly, Table 2 also provides indications of the relationship between the variables: information quality and the direct use of the Infinium HR system in the management of teaching staff. This is explained using the unstandardised and standardised coefficients. At the $\mathrm{MoE}$ level, an increase of one point in the information quality variable implies an increase of 0.746 in the direct use variable. That is, if the 'direct use' variable increases by one point, it moves for example, from the ' 0 hours' of direct use value to ' $1-2$ hours' value (or from ' $3-4$ hours' to '5-6 hours' etc.) per week. In other words in terms of the standardised coefficients, an increase of one standard deviation in information quality produces an increase of 0.282 standard deviations in direct use above the mean. That is, $11.03 \%$ over the mean. In addition, $17.3 \%\left(\mathrm{R}^{2}\right)$ of the variance in direct use is explained by information quality. 


\subsection{How System Quality Features Relate to Indirect Use}

Table 3 shows the significance of $\mathrm{F}$ at $p=0.000(p=<0.05)$ for both models ( 1 and 2), suggesting that the null hypothesis (on indirect use) is rejected. Thus, there is a significant linear relationship between the system quality features and indirect use in the management of teaching human resource in the MoE.

Table 3. ANOVA test on the null hypothesis on indirect use

\begin{tabular}{llcccccc}
\hline Model & & $\begin{array}{c}\text { Sum of } \\
\text { Squares }\end{array}$ & df & Mean Squares & F & Sig. \\
\hline 1 & Regression & 23.951 & 3 & 7.984 & 6.837 & .018 \\
& Residual & 129.614 & 111 & 1.168 & & \\
& Total & 153.565 & 114 & & & \\
\hline 2 & Regression & 22.318 & 2 & 11.159 & 9.523 & .000 \\
& Residual & 131.247 & 112 & 1.172 & & \\
& Total & 153.565 & 114 & & & \\
\hline 1 & R squared $\left(\mathrm{R}^{2}\right)$ & .329 & $32.9 \%$ & & & \\
2 & R squared (R & & & & \\
& & .292 & $29.2 \%$ & & & & \\
\hline
\end{tabular}

1. Predictors: (Constant), Quality of output options, Software quality, Information quality

2. Predictors: (Constant), Quality of output options, Information quality

Dependent Variable: INDIRECT

In model 2 when the variable software quality is removed, the $F$-value increases from 6.837 to 9.523 and there is little change in the sum of squares, 23.951 to 22.318 , suggesting the contribution of the variable, software quality, was insignificant (significance of $\mathrm{F}$ at 0.240 ) in the indirect use of the Infinium HR system (Table 4). The results of model 2 are therefore considered in the analysis.

Table 4. System quality features influence on indirect use

\begin{tabular}{|c|c|c|c|c|c|c|}
\hline Model & Main effects & $\begin{array}{c}\text { Unstandardised } \\
\text { Coefficients Beta }\end{array}$ & $\begin{array}{l}\text { Std. } \\
\text { Error }\end{array}$ & $\begin{array}{c}\text { Standardised } \\
\text { Coefficients Beta }\end{array}$ & $t$ & $\begin{array}{c}\text { Significance } \\
\text { of } \mathrm{F}\end{array}$ \\
\hline \multirow{4}{*}{ I } & (Constant) & 3.279 & .597 & & 5.492 & .000 \\
\hline & $\begin{array}{l}\text { Information } \\
\text { Quality }\end{array}$ & .565 & .221 & .236 & 2.560 & .040 \\
\hline & Software Quality & .474 & 401 & .104 & 1.182 & .240 \\
\hline & $\begin{array}{l}\text { Quality of output } \\
\text { options }\end{array}$ & 697 & 249 & .256 & 2.804 & .010 \\
\hline \multirow[t]{3}{*}{2} & (Constant) & 3.723 & 465 & & 8.008 & .000 \\
\hline & $\begin{array}{l}\text { Information } \\
\text { Quality }\end{array}$ & .531 & .219 & .221 & 2.420 & .001 \\
\hline & $\begin{array}{l}\text { Quality of output } \\
\text { options }\end{array}$ & .689 & .249 & .253 & 2.766 & .027 \\
\hline
\end{tabular}

The unstandardised coefficients for information quality of 0.531 in model 2 (Table 4) tells us that an increase by one unit of information quality increases the indirect use by an average of 0.531 points on the six-point scale $((1=0$ hours, $2=1-2$ hours, $3=3-4$ hours, $4=5-10$ hours, $5=11-15$ hours, $6=$ 
$>15$ hours) per week. In the same way, a one point increase in the 'quality of data output options' increases the indirect use of the Infinium HR system by an average of 0.689 points on the six point scale. Using standardised scores, an increase of one standard deviation in information quality or quality of output options produces an increase of 0.221 or 0.253 standard deviations respectively, in the dependent variable indirect use. Furthermore, $29.2 \%$ of the variance in indirect use is explained by information quality and quality of output options in model 2 (Table 3 )

The findings with respect to the effects of system quality features show that quality of information from the Infinium HR system has a relationship with both the direct and indirect use of the Infinium HR system in the management of teaching personnel by the MoE. In addition, a variable closely related to information quality, 'quality of output options' had influenced indirect use of the system by the MoE end users. However, the variable, quality of software appears not to affect either the direct or indirect use by the MoE.

\subsection{How Implementation Process Features relate to Direct Use}

Table 5 shows the results of a three-step backwards regression analysis with the variable, clarity of innovation goals removed in model 2 , and the variables clarity of innovation goals and performance of the Change Facilitator System (CFS) (the technical team) removed in model 3. Table 6 shows that there is no significant independent relationship between the removed variables and direct use of the Infinium HR system.

Table 5. ANOVA test on the impact of implementation process features on direct use

\begin{tabular}{llccccc}
\hline Model & & $\begin{array}{c}\text { Sum of } \\
\text { Squares }\end{array}$ & df & $\begin{array}{c}\text { Mean } \\
\text { Square }\end{array}$ & F & $\begin{array}{c}\text { Significance of } \\
\text { F }\end{array}$ \\
\hline 1 & Regression & 36.608 & 3 & 9.51 & 7.049 & .045 \\
& Residual & 149.687 & 111 & 1.349 & & \\
& Total & 186.296 & 114 & & & .012 \\
\hline 2 & Regression & 36.430 & 2 & 12.862 & 9.613 & \\
& Residual & 149.865 & 112 & 1.338 & & .000 \\
& Total & 186.296 & 114 & & & \\
\hline 3 & Regression & 34.250 & 1 & 21.558 & 16.016 & \\
& Residual & 152.046 & 113 & 1.346 & & \\
& Total & 186.296 & 114 & & & \\
\hline 3 & R squared $\left(\mathrm{R}^{2}\right)$ & & 27.3 & $27.3 \%$ & & \\
\hline
\end{tabular}

1. Predictors: (Constant), Performance of CFS, Amount of External training, Clarity of innovation goals

2. Predictors: (Constant), Performance of CFS, Amount of external training

3. Predictors: (Constant), Amount of external training.

Dependent Variable: DIRECT 
The amount of external training seems to be the most powerful source of explaining the variance in direct use. The standardised coefficient of the variable external training is at 0.429 (Table 6), suggesting that an increase by one standard deviation in the amount of external training produces an increase of 0.429 standard deviations above the mean of direct use of the Infinium HR system. Therefore, an increase of one standard deviation in the amount of external training yields an increase of $18.79 \%$ of direct use above the mean ( 7.5 hours per week). Additionally, 27.3\% (Table 5) of the variance in direct use of the Infinium HR system is explained by the independent variable 'amount of external training.'

Table 6. Impact of implementation process features on the direct use

\begin{tabular}{llccccc}
\hline Model & Main effects & $\begin{array}{c}\text { Unstandardised } \\
\text { Coefficients Beta }\end{array}$ & $\begin{array}{c}\text { Std. } \\
\text { Error }\end{array}$ & $\begin{array}{c}\text { Standardised } \\
\text { Coefficients Beta }\end{array}$ & $\mathrm{t}$ & $\begin{array}{c}\text { Significance } \\
\text { of F }\end{array}$ \\
\hline 1 & (Constant) & 2.577 & .740 & & 3.483 & .001 \\
& $\begin{array}{l}\text { External training } \\
\text { Clarity of }\end{array}$ & 1.136 & .229 & .441 & 4.959 & .000 \\
& $\begin{array}{l}\text { innovation goals } \\
\text { Performance of }\end{array}$ & .419 & .345 & .104 & 1.215 & .227 \\
& & & & & & \\
& CFS & 230 & .033 & .363 & .717 \\
\hline 2 & (Constant) & 1.643 & .714 & & 3.701 & .000 \\
& External training & .435 & .341 & .108 & 1.277 & .204 \\
& $\begin{array}{l}\text { Performance of } \\
\text { CFS }\end{array}$ & & & & & \\
\hline 3 & (Constant) & 3.452 & .330 & & 10.456 & .000 \\
& External training & 1.104 & .219 & .429 & 5.045 & .000 \\
\hline
\end{tabular}

\subsection{How Implementation Process Features Relate to Indirect Use}

Table 7 shows the results of a three-step backwards regression analysis with the variable, clarity of innovation goals removed in model 2, and the variables clarity of innovation goals and performance of the CFS removed in model 3.

Table 7. The impact of implementation process features on indirect use

\begin{tabular}{llccccc}
\hline Model & & $\begin{array}{c}\text { Sum of } \\
\text { Squares }\end{array}$ & df & $\begin{array}{c}\text { Mean } \\
\text { Square }\end{array}$ & F & $\begin{array}{c}\text { Significance of } \\
\text { F }\end{array}$ \\
\hline 1 & Regression & 15.983 & 3 & 5.328 & 4.298 & .382 \\
& Residual & 137.582 & 111 & 1.239 & & \\
& Total & 153.565 & 114 & & & .042 \\
\hline 2 & Regression & 15.638 & 2 & 7.819 & 6.349 & \\
& Residual & 137.927 & 112 & 1.231 & & .000 \\
& Total & 153.565 & 114 & & & \\
\hline 3 & Regression & 14.723 & 1 & 14.723 & 11.983 & \\
& Residual & 138.842 & 113 & 1.229 & & \\
& Total & 153.565 & 114 & & & \\
\end{tabular}




\begin{tabular}{cccccc}
\hline Model & $\begin{array}{c}\text { Sum of } \\
\text { Squares }\end{array}$ & df & $\begin{array}{c}\text { Mean } \\
\text { Square }\end{array}$ & F & $\begin{array}{c}\text { Significance of } \\
\mathrm{F}\end{array}$ \\
\hline $\mathrm{R}$ squared $\left(\mathrm{R}^{2}\right)$ & 0.225 & $22.5 \%$ & & & \\
\hline
\end{tabular}

1. Predictors: (Constant), Performance of CFS, Amount of external training, Clarity of innovations goals

2. Predictors: (Constant), Amount of external training, Clarity of innovations goals

3. Predictors: (Constant), Amount of external training

Dependent Variable: INDIRECT

Furthermore, Table 8 shows that the performance of CFS and clarity of innovation goals have significance values of $F$ at greater than 0.05 , suggestive of the variables having no significant independent relationships with the indirect use of the Infinium HR system. The significance of $F$ in model 3 is at 0.000 , thus the null hypothesis is rejected. It is further observed that the sum of squares change is very small across the models (from 15.983 in model 1 to 14.723 in model 3) while the corresponding values of mean squares increased from 5.328 (significance of $F=0.382$ ) to 14.723 (significance of $\mathrm{F}=0.000$ ).

Table 8. Impact of implementation process features on the indirect use

\begin{tabular}{llccccc}
\hline Model & Main effects & $\begin{array}{c}\text { Unstandardised } \\
\text { Coefficients Beta }\end{array}$ & $\begin{array}{c}\text { Std. } \\
\text { Error }\end{array}$ & $\begin{array}{c}\text { Standardised } \\
\text { Coefficients Beta }\end{array}$ & $\mathrm{t}$ & $\begin{array}{c}\text { Significance } \\
\text { of F }\end{array}$ \\
\hline 1 & (Constant) & 2.723 & .709 & & 3.839 & .000 \\
& $\begin{array}{l}\text { External training } \\
\text { Clarity of }\end{array}$ & .667 & .220 & .285 & 3.036 & .003 \\
& $\begin{array}{l}\text { innovation goals } \\
\text { Performance of }\end{array}$ & .203 & .221 & .087 & .919 & .360 \\
& & & & & \\
& CFS & .174 & .331 & .048 & .527 & .599 \\
\hline 2 & & & & & & \\
& (Constant) & 3.030 & .403 & & 7.523 & .000 \\
& External training & .668 & .219 & .286 & 3.050 & .003 \\
& $\begin{array}{l}\text { Performance of } \\
\text { CFS }\end{array}$ & .188 & .218 & .081 & .862 & .390 \\
\hline 3 & (Constant) & 2.814 & .316 & & 8.921 & .000 \\
& External training & .724 & .209 & .310 & 3.462 & .000 \\
\hline
\end{tabular}

The standardised coefficient for 'amount of external training' of 0.724 (Model 3, Table 8) implies that an increase by one point on external training variable increases the indirect use of the Infinium HR system by an average of 0.724 on the six-point scale. Alternatively, in terms of standardised scores, an increase of one standard deviation in amount of external training produces an increase of 0.310 standard deviations in indirect use of the Infinium HR system. This means indirect use of the system increases by $12.93 \%$ above the mean (per week).

The findings on the relationship of implementation process features suggest that amount of external training of the end users is a factor in explaining the variances in both the direct use and indirect use of the Infinium HR system in the management of teachers by the MoE. 


\subsection{How Organisational Process Features Relate to Direct Use}

This section examines and analyses data collected on the impact of organisational process features on use (direct or indirect). The variables that constitute organisation features are the Infinium goals, motivation before implementation, and computer experience. These three independent variables were considered in the backwards regression analysis.

As noted on the footnote of Table 9, all organisational features variables were entered in model 1 , perceived IS goals was removed in model 2 , and then in model 3 perceived IS goals and motivation before implementation were both removed implying that these factors did not have a significant independent relationship on the direct use of the Infinium HR system. However, the significance of $F$ is at 0.008 (Table 9), suggesting that the null hypothesis (direct) is rejected, as there is linear significant relationship between the predictors and dependent variable direct use.

Table 9. The impact of organisational process features on direct use

\begin{tabular}{llcccc}
\hline Model & \multicolumn{1}{c}{ Main effects } & $\begin{array}{c}\text { Unstandardised } \\
\text { Coefficients Beta }\end{array}$ & $\begin{array}{c}\text { Std. } \\
\text { Error }\end{array}$ & $\begin{array}{c}\text { Standardised } \\
\text { Coefficients Beta }\end{array}$ & $\begin{array}{c}\text { t } \\
\text { (Constant) } \\
\text { Motivation before }\end{array}$ \\
$\begin{array}{l}\text { implementation } \\
\text { Perceived IS goals }\end{array}$
\end{tabular}


The variable 'computer experience' explains $33.8 \%$ of the variance in direct use. This variable has a standardised coefficient of 0.248 . Therefore, an increase by one standard deviation in the variable 'computer experience' results in an increase of direct use by $10.26 \%$ above the mean. The conclusion reached here is that an increase in computer experience of the end users would result in increased direct use of the Infinium HR system.

\subsection{How Organisational Process Features Relate to Indirect Use}

Table 10. The impact of organisational process features on indirect use

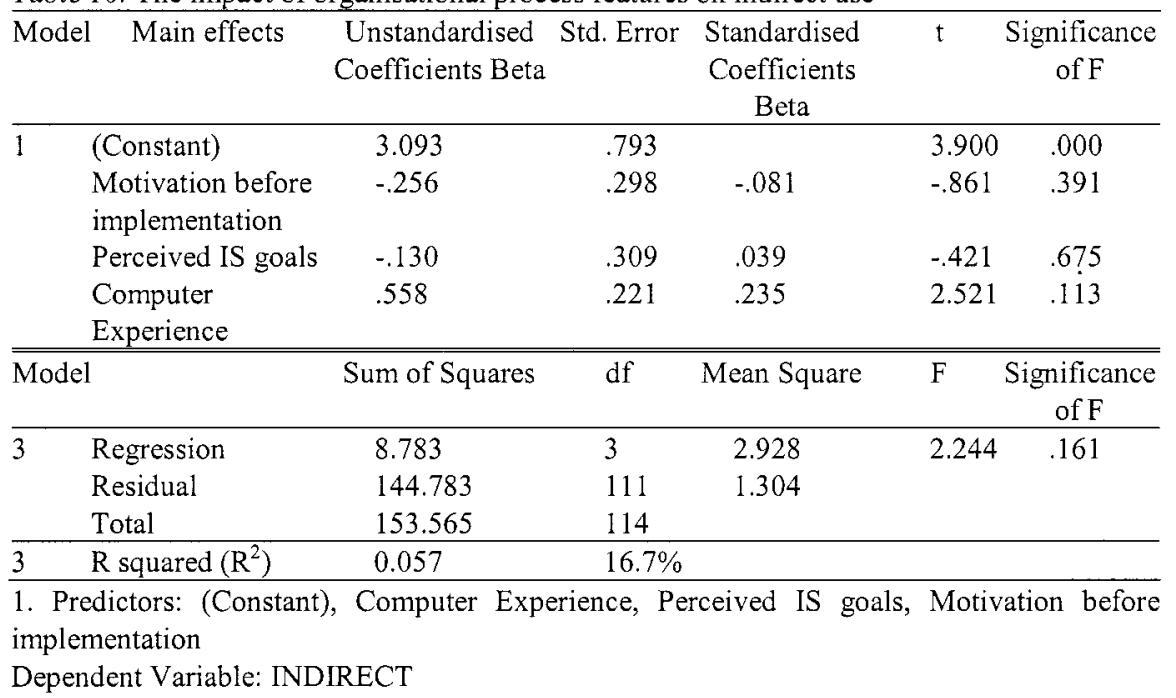

The summary Table 10 on the main effects depicts significance of $F$ of the predictors on indirect use at 0.161 , which is not statistically significant at $p>0.05$. Therefore, the null hypothesis is accepted, that there is no linear relationship between organisational process features and the indirect use of the Infinium HR system in the management of teaching staff. In addition, the three independent variables, motivation before implementation, perceived IS goals and computer experience within the MoE have no significant impact on the indirect use of the database. Although $16.7 \%\left(\mathrm{R}^{2}\right)$ of the variance in indirect use is explained by the three predictors it was not statistically significant.

\section{CONCLUSION}

Three factors thought to influence system quality - information quality, quality of software, and quality of output options were analysed with respect 
to their effects on direct and indirect use of the Infinium HR system. Both direct and indirect use was affected by information quality. In addition, a variable closely related to information quality namely quality of output options had influenced indirect use of the system by the MoE end users. However, the variable quality of software appears not to affect either the direct or indirect use by the MoE. With respect to the implementation procedure, the critical factor effecting indirect and direct usage was the amount of external training of the users. As regards organisational processes, the only conclusion that can be drawn is that an increase in computer experience of the end users would result in an increased direct use of the Infinium HR system, but no increase in indirect usage.

To conclude, this paper highlights some of the factors that influence direct and indirect use of the Infinium HR system as implemented for managing the teaching resource in the $\mathrm{MoE}$ in Botswana. However, it should be noted that the amount of use might have been influenced by other factors. Botswana is a developing country and as Riggs (1964) asserts, in prismatic societies there is a tendency of the new and the old to sit side by side. That is, although a new system has been introduced, the system remains unused by the user organisation. Unfortunately, space does not permit the investigation of this hypothesis here.

\section{REFERENCES}

MoE (1994). The Revised National Policy on Education (RNPE). Gaborone, Botswana Government Printer

Kereteletswe O.C. and Selwood I.D. (2003). The Implementation of Information Technology in Educational Management in Botswana in Selwood, I.D., Fung, A.C.W., \& O'Mahony C. (Eds) Management of Education in the Information Age - The Role of ICT. Boston: Kluwer.

Riggs Fred, W. (1964) Administration in Developing Countries: The Theory of Prismatic Society. Boston: Houghton

Visscher, A.J. (1995). 'Computer assisted school administration and management: where are we and where should we go?' In Information Technology in Educational Management. Edited by Ben Zion Barta, Moshe Telem and Yaffa Gev. Chapman Hall for IFIP, London. 